\title{
RECENT RESEARCHES ON ARTHRITIS AND RHEUMATISM IN THE UNITED STATES*
}

\author{
BY PHILIP S. HENCH \\ Division of Medicine, The Mayo Clinic, Rochester, Minnesota.
}

Among chronic diseases in the United States "rheumatism" ranks first in prevalence, second in producing disability, second in producing invalidity (permanent disability) and fourteenth in causing death. Among the $127,000,000$ persons in the United States there are 6,850,000 with " rheumatism," considerably more than the combined figures of those with heart disease $(3,700,000$ cases), cancer and other tumours (930,000 cases), tuberculosis $(680,000$ cases $)$ and diabetes $(660,000$ cases $)$ altogether. Such were the figures obtained in a recent National Health Survey ${ }^{1}$ in which " rheumatism included arthritis, gout, neuralgia, neuritis, lumbago, etc." Another survey reported that there were annually disabled about 1,500,000 Americans with "arthritis," and an additional 1,750,000 persons with neuralgia, neuritis and lumbago. ${ }^{2}$ These figures again indicate the enormous morbidity produced by the " rheumatic diseases."

\section{Gonorrhalal Arthritis}

In the United States there are annually about $1,037,000$ cases of acute, and about an equal number of cases of chronic, gonorrhoea. ${ }^{3}$ Recent statistics indicate that about 1 to 3 per cent. of such patients develop gonorrhœal arthritis.4

DIAGNOSIS.- Since the newer forms of treatment of gonorrhœa and gonorrhœal arthritis are so highly successful it is more important than ever to make the diagnosis in such cases early and promptly in order to prevent the gross articular destruction that might otherwise result from delayed treatment. Suggested criteria 5, 6 for a diagnosis of "proved gonorrhœal arthritis" are: (1) a history of recent or existing gonorrhœa, (2) clinical evidence of genital gonorrhœa, (3) isolation of gonococci from a primary

* Submitted for publication February 28, 1939. 
focus, (4) the presence of acute or subacute joint disease having the recognised clinical characteristics of gonorrhœal arthritis, (5) demonstration of gonococci in synovial fluid, (6) a positive gonococcal complement-fixation test on blood or synovial fluid, or both. In certain cases a positive diagnosis of gonorrhœal arthritis is made by the isolation of gonococci from joint fluid or tissues even in the absence of several or all of the other criteria noted. A diagnosis of " probable gonorrhœal arthritis" is justified even in the absence of points (5) and (6), when the first four criteria are present, particularly if the patient makes a prompt response to a therapeutic test with sulphanilamide or artificial fever.

The clinical characteristics of several large new series of cases of proved gonorrhœal arthritis were presented. ${ }^{5-7}$ A curious feature was noted: respiratory symptoms, apparently a part of the systemic toxæmia, often preceded the arthritis; in connection with febrile polyarthritis this often led to an erroneous diagnosis of rheumatic fever. Recently stressed as a feature of some diagnostic importance in systemic gonorrhœa were skin lesions, described ${ }^{5,8.11}$ as scattered petechiæ (small red sore spots or slightly tender, circumscribed, purplish-red areas, $2 \mathrm{~mm}$. to $1 \mathrm{~cm}$. in diameter, chiefly on extremities, many having a central white area of necrosis, a few with vesiculation and sero-purulent fluid), or as an eruption (maculo-papular, in some areas hæmorrhagic, rapidly becoming vesicular, then pustular). Such lesions were generally associated with frank gonococcæmia, with or without endocarditis.

Since about 80 per cent. of gonococcal complement-fixation tests done in their cases of proved gonorrhœal arthritis were positive, some 5, 6. 12 considered the test an important diagnostic aid; others, ${ }^{13}$ however, considered it unreliable because false positive tests often were obtained on patients without gonorrhœa. Bactericidal antibodies against gonococci appear in blood and in synovial fluid of patients who have gonorrhœal arthritis with sterile joint fluid and without gonococcæmia. Such antibodies, however, are low or absent in blood and synovial fluid of patients with infected joint fluid or with gonococcæmia. ${ }^{14}$ Thus the prevention of bacteræmia seems to depend on the antibody content of blood or on an efficient local defence reaction in the primary focus of infection. Gonococci tend to localise and survive in regions amply supplied with mucin (urethra, cervix, conjunctiva, joints). Synovial mucin assists some strains of 
gonococci to survive when synovial fluid antibodies are low, but not when they are high. ${ }^{14}$

Treatment.-Until the advent of sulphonamide compounds, induced fever constituted the most promptly effective treatment ever devised for gonorrhœa and gonorrhœal arthritis. Although fever therapy has been largely (but not completely) supplanted by the use of sulphanilamide no one should discount the extremely valuable, highly scientific and courageous pioneer work of those who collaborated in its development. Further experiences have amply shown that fever therapy provides a potent weapon against gonococcal infections. In the literature reviewed for this survey about a dozen new reports presented the results of fever therapy in about 350 cases of gonorrhœal arthritis. 15.23 Prompt cure was obtained in about 75 to 90 per cent. of all cases in which it was employed. Best results were noted in the more acute cases, in which treatment was begun before irreparable articular damage had had time to occur. In most cases the genital lesions also responded satisfactorily to fever therapy, but in the treatment of females superior results were noted from " combined heating"; this term denotes systemic fever produced by fever cabinets or short-wave diathermy and additional heating of the pelvis by the use of pelvic diathermy electrodes. ${ }^{15,} 16$ Single long sessions of artificial fever, long enough to kill each patient's particular strain of gonococcus (average 14.8 hours at $41 \cdot 5^{\circ} \mathrm{C}$.) were recommended by some ${ }^{16,22,} 23$ to accomplish " one-treatment cures."

Worthy of special note were two reports which ${ }^{24,}{ }^{25}$ compared the results of fever therapy for gonorrhœa and gonorrhœal arthritis with those from older methods of treatment (physical therapy to joints; local chemotherapy to genital lesions). Cures were obtained in 76 per cent. of cases of acute gonorrhœal arthritis, and in 24 per cent. of cases in which chronic gonorrhœal arthritis was treated by fever, but cure resulted in only 8 per cent. and 5 per cent. respectively of a similar number of acute and of chronic cases in which treatment was by other methods. The average period of hospitalisation in the cases in which treatment was not by fever was just twice as long (forty-five days) in the acute cases and three and one-half times as long (156 days) in the chronic cases as it was in those in which treatment was by fever. In another series of cases of gonorrhœea with non-articular complications the percentage of patients cured by fever was definitely higher than those cured by older methods, and with fever therapy cures were 
obtained in a third to a fourth of the time required by older methods. ${ }^{25}$

Minor complications (herpes, headaches, gastro-intestinal symptoms, tetany, mild burns) affected about 20 to 30 per cent. of patients subjected to fever therapy.4. 26 Serious or fatal complications rarely occur when fever therapy is applied by a trained personnel. In 1937 only eleven deaths related to fever therapy were reported in connection with many thousands of sessions of fever; the mortality rate was less than 0.2 per cent. Some ${ }^{27 .} 28$ regarded anoxæmia as perhaps the chief cause of major complications, and for their prevention advocated administration of oxygen and carbon dioxide and avoidance of sodium amytal or epinephrine during sessions of fever.

The development of sulphonamide compounds and their application to the treatment of disease bids fair to rank among the great therapeutic advances. For one thing, it has established beyond all doubt that chemical "specifics" can be developed not only, as in the past, for non-bacterial (protozoan) infections, but also for microbic diseases. Physicians everywhere can well thrill to this chapter in medical research, a chapter which is still unfolding and which reveals a story of international co-operation that a sorry world of politics might well copy. Born of German chemical researches, the work has been developed and extended by physicians in many countries and of many nationalities, perhaps in particular in England, France and the United States. Those concerned with the care of patients with articular diseases should in particular familiarise themselves with the development of this work, because, as the work is being extended, it would appear that certain sulphonamide compounds can be successfully applied to the treatment not only of gonorrhœal arthritis, but also of the rarer but most troublesome articular lesions due to beta-hæmolytic streptococci, meningococci, pneumococci, perhaps also to Brucella melitensis, typhoid bacilli and other bacteria as well. Those interested may find a summary of the earlier work on prontosil and sulphanilamide (through 1937) in the Fifth Rheumatism Review just prepared for the American Rheumatism Association.4

Sulphanilamide was introduced to American physicians in January, 1937, by Long and Bliss, who in a series of papers ${ }^{29-31}$ described its effects on experimental infections and on infections of human beings with beta-hæmolytic streptococci. They and others $^{4}$ soon applied the substance in the treatment of pneumo- 
coccic and meningococcic infections, and in May, 1937, reports of its successful use in gonorrhœa were published almost simultaneously by Dees and Colston ${ }^{32}$ and by Reuter. ${ }^{33}$ The development by Marshall, Emerson and Cutting ${ }^{34}$ of tests for the quantitative determination of sulphanilamide in body fluids and studies on its absorption and excretion led to more effective methods for its administration. The exact mode of action of the prontosils and of sulphanilamide is still obscure. The original idea that perhaps the prontosils were effective only in relation to their quantitative reduction to sulphanilamide does not satisfy some $e^{4,35}$ who have noted good results from sulphonamide compounds which cannot be reduced to sulphanilamide in vivo, and from amounts of prontosil solution which liberate only a few grains of sulphanilamide a day. Space cannot be given here for a review of the American reports on the toxic manifestations of sulphanilamide; in the review noted ${ }^{4}$ these were described: sulphanilamide fever, the gastro-intestinal, renal and nervous symptoms, skin rashes, acidosis, leukopenia, acute hæmolytic anæmia, agranulocytosis, cyanosis, sulphæmoglobinæmia and methæmoglobinæmia. In general, sulphanilamide and related compounds are either nontoxic or only mildly toxic to man. Serious reactions occur only rarely. Among the first 4,000 cases reported, in which patients were treated with these compounds, only ten deaths apparently related to the drug occurred ${ }^{36}$ in five of them the drug may not have been the actual cause of death. Deaths occurred almost exclusively from agranulocytosis. ${ }^{4}$ (This does not include the deaths from elixir of sulphanilamide Massengill, which were due, of course, not to the sulphanilamide, but to the solvent.)

Among the early patients with gonorrhœa treated with sulphanilamide were only a few with arthritis, but the results were "dramatic," " astonishing," prompt cures generally being

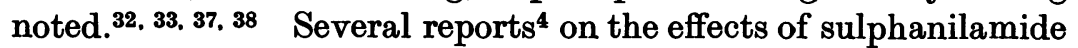
in cases of gonorrhcea without arthritis appeared; when adequate doses were given, prompt cures were effected in 80 to 90 per cent. of cases. In some of the earlier cases inadequate doses were given. With experience, the tendency has been to use larger and more effective doses and to continue administration of the drug for a sufficient length of time to give more certainty of its complete effectiveness, rather than to reduce the dose or stop administration of the drug prematurely. In general the dose used has been that recommended by Long and Bliss ${ }^{30}$ to obtain and maintain 
an effective concentration of the drug in the blood (a daily dose of $\frac{3}{4}$ grain sulphanilamide per pound of body weight, with a constant intake of fluid).

Because of toxicity of the drug for certain patients, they cannot take sulphanilamide in effective amounts; other patients may be infected with strains of gonococci unusually resistant to the drug (as certain strains were found to be resistant to fever therapy). In some cases in which patients are resistant to sulphanilamide or to fever therapy alone the combination of sulphanilamide (40 to 80 grains daily) with one to three rather short sessions of fever (three to four hours at $103^{\circ}$ or $104^{\circ} \mathrm{F}$.) were reputedly successful. ${ }^{39}, 40$ My colleagues and $I^{4}$ also have noted successes with this combination, which seems indicated primarily if patients are truly resistant to full doses of the drug, or are tolerant of only small doses. The combination of fever therapy and sulphanilamide also has been suggested for those patients who urgently need an immediate cure for domestic or economic reasons.

A few reports on older methods of treatment may be noted. Some investigators considered gonococcus vaccine ${ }^{41}$ or auto-serotherapy ${ }^{42}$ effective; others found the intra-articular injections of specific antigonococcal serum ${ }^{43}$ and the use of Corbus-Ferry filtrate $^{44}{ }^{45}$ of little or no value.

\section{Tuberculous Arthritis}

The clinical features presented in 122 cases of juvenile tuberculous spondylitis were reported. ${ }^{46}$ Tuberculosis affected the lungs in 60 per cent., joints in addition to those of the spinal column in 20 per cent. of the cases. Spinal lesions were cervical in 4 per cent., thoracic in 77 per cent., lumbar in 16 per cent., lumbo-sacral in 3 per cent. Abscesses afflicted. 75 per cent., paraplegia 7 per cent. of the patients. Spontaneous intervertebral fusion, a rare event, occurred in six cases. Of the 122 patients, 16 per cent. died, often with amyloidosis. Some recent writers ${ }^{46,47}$ favoured prolonged conservative treatment (long immobilisation on a convex hyperextension frame) before performing fusion in cases of juvenile Pott's disease, an opinion in contrast to that of others who expressed the belief that much time and some lives can be saved by early fusion. 


\section{Pneumococcal Arthritis}

Pneumococcal arthritis is rare. Among a series of 1,800 cases of pneumonia, only two cases of pneumococcal arthritis were encountered. ${ }^{48}$ The condition generally accompanies pneumonia, but may accompany pneumococcal septicæmia without pneumonia. Monarthritis usually is present; articular function may be seriously impaired, or it may be completely restored if joints are adequately drained. Diagnosis rests on isolation of pneumococci from joints. A number of reports ${ }^{4}$ indicate that sulphanilamide may be effective against certain types of pneumococcal infection. In particular, American physicians are awaiting with interest further reports on the value of sulphapyridine against pneumococci. If the preliminary English reports on its value are corroborated, pneumococcal arthritis may become even rarer than it is now.

\section{SYPHILIS OF JoINTS}

A survey of recent literature on tabetic Charcot joints was made $^{49}$ to review their clinical features. Tabetic articular lesions usually are single and commonly affect lower extremities; an unusual case was reported, that of a man with multiple tabetic arthropathies. Charcot joints are not notably affected by antisyphilitic treatment, but some believe they may be prevented by fever therapy of early syphilis or early tabes.4

\section{Articular Lesions from Brdcellosis: Undulant (Malta) Fever}

Symptoms referable to muscles and joints are common, sometimes dominant, features of brucellosis of man. They are often produced by caprine strains, less commonly by porcine, and rarely by bovine strains of Brucella. Arthralgia of varying severity affected 30 to 40 per cent. of recent Amcrican patients. ${ }^{50-53}$ Migratory and polyarticular, the arthralgia was commonly misdiagnosed "rheumatic fever." Frank arthritis occurred only occasionally $;^{52}$ painful ${ }^{54}$ and painless ${ }^{50}$ hydrarthrosis was seen.

In the United States, between 1928 and 1934, 9,317 cases with 374 deaths were reported, evidence that the incidence of the disease or its recognition, or both, are rapidly increasing. These figures have been compared to European statistics. ${ }^{55}$ Current 
studies stress the fact that no type of fever is pathognomonic of the disease, fever is often absent, symptoms are multiple and physical findings are scarce; hence the dictum: "Think of brucellosis in all cases of prolonged ill-defined sickness, in all cases of unexplained fever, especially without localising signs, and in all cases of prolonged disability of the neurasthenic type."

Certification of the diagnosis rests on laboratory tests, which unfortunately are neither easy nor consistently helpful. Some expressed the belief that agglutination tests which are positive in any titre are indicative of disease and are more reliable than skin tests; others favoured the latter. ${ }^{4}$

Since spontaneous remissions and cures occur, therapy is difficult to evaluate. Brucella abortus vaccine seemed valuable to some, ${ }^{56}$ of little value to others. Several patients appeared to be cured by the use of induced fever. 4 The worth of sulphanilamide and related compounds is being studied; final conclusions have not been reached.

\section{Meningococcic Arthritis}

American workers have confirmed the observation of their English colleagues that meningococcal infections, including those of joints, are amenable to treatment by sulphanilamide.4. 57 Three cases of meningococcic arthritis in which treatment by sulphanilamide was successful were reported. ${ }^{30 .}{ }^{58}$ Some $^{59}$ consider the combined use of serum and sulphanilamide superior to the use of either alone.

\section{Articular Diseases due to Hamolytic Streptococci}

Since sulphanilamide has been found to be so effective against beta-hæmolytic streptococci, it is particularly important to recognise the bacteriologic identity of articular complications from such bacteria. Articular complications may occur with puerperal sepsis, scarlet fever, hæmolytic streptococcal osteomyelitis, streptococcic sore throat or otitis media, and hæmolytic streptococcæmia. 29, 30, 31 In a few cases of metastatic arthritis with puerperal sepsis, ${ }^{60}$ hæmolytic streptococcæmia ${ }^{61}$ and hæmolytic streptococcal meningitis, ${ }^{62}$ cure by sulphanilamide has been reported. 


\section{Scarlatinal Arthritis}

Three articular complications of scarlet fever are recognised: type 1, non-suppurative scarlatinal arthritis with sterile exudates; type 2, suppurative scarlatinal arthritis with hæmolytic streptococci in purulent exudates; type 3, scarlatinal or post-scarlatinal rheumatism, in reality the polyarthritis of latent rheumatic fever activated by scarlatinal streptococci. Among 5,549 patients with scarlet fever seen by one physician ${ }^{63}$ were ninety-nine cases of true scarlatinal arthritis (types 1 and 2), an incidence of 1.8 per cent. The effect of sulphanilamide in preventing or curing such arthritic conditions is being studied.

\section{Rheumatic Fever}

Cuinical Data.-Rheumatic carditis affected the school children on two northern American Indian reservations nine times as often as those on a southern reservation; ${ }^{64}$ the hospital incidence of rheumatic carditis in Chicago was more than four times as great as that in the southern city of Galveston. ${ }^{65}$ These are further evidences of the greater predilection for the disease in the northern States. A study of 112 rheumatic families led to the conclusion that an hereditary factor, transmitted as a single autosomal recessive gene, is distributed among the population, which makes the bearer susceptible to rheumatic fever, ${ }^{66}$ but hereditary susceptibility may not be the sole requirement for its development. The symptomatology of several hundred new cases of rheumatic fever was analysed..$^{4}$ Among a population of about 130,000,000 there are more than 1,000,000 Americans with rheumatic carditis, and 40,000 deaths therefrom each year, the average age at death being thirty years. ${ }^{67}$ Some believe that adult heart valves practically never possess bloodvessels; when seen they are the result, not the predisposing factor, of antecedent rheumatic inflammation. ${ }^{68}$ Others believe that most normal heart valves possess bloodvessels, but their incidence in a given valve does not correspond to the incidence of rheumatic valvulitis in that valve, since active or healed valvulitis can be found in the absence of bloodvessels. ${ }^{69}$ By injecting 2 to 3 c.c. of the rheumatic patient's own blood into the region of the olecranon, subcutaneous nodules were produced in 45 per cent. of eighty-two rheumatic patients; in only one of thirty-four 
non-rheumatic persons.70 The histologic characteristics of these induced nodules were essentially similar to those of spontaneous type. According to one writer, ${ }^{71}$ there is no sound evidence that erythema nodosum is related to rheumatic fever. Another physician, ${ }^{72}$ after studying 143 cases of erythema nodosum, regarded rheumatic fever merely as one of several provocatives of erythema nodosum, a non-specific skin reaction to various toxins.

Laboratory Data.-The value of lead IV electrocardiograms in rheumatic fever is in dispute; some ${ }^{73}$ consider them superior to, others ${ }^{74}$ regard them as of no more value than, orthodox leads in giving evidence of rheumatic carditis.

ETTOLOGY.-No new hypotheses or important variants of old hypotheses have been elaborated. The relationship of streptococcal pharyngitis to rheumatic fever remains obscure; studies made in New York City indicated a close connection between the two ${ }^{75}$ others made in Galveston, Texas, did not. ${ }^{65}$ Although the skin of rheumatic patients is hypersensitive to streptococci, especially to hæmolytic streptococci, this is no proof that hæmolytic streptococci are of ætiological importance; one worker ${ }^{76}$ found that the positivity of skin tests was directly proportional to the content of non-specific irritant substances. Many patients with rheumatic fever possess anti-C precipitins (antibodies against the $\mathrm{C}$, or carbohydrate, fraction of hæmolytic streptococci), but so do some normals and some patients with other articular diseases; such precipitins are not specific for rheumatic fever and must be interpreted with caution. ${ }^{77}$

The argument suggesting a relationship between rheumatic fever and deficiency of vitamin $\mathrm{C}$ has been restated, ${ }^{78}$ but not especially strengthened, by newer work. Obviously the cause of the disease remains unknown. Many still believe that rheumatic fever is closely related to beta (but not to alpha or gamma) hæmolytic streptococci, and the fact has been stressed that the naso-pharyngeal infections which precipitate rheumatic fever are mostly due to group A (Lancefield) hæmolytic streptococci. But if this is so, why is sulphanilamide, which is so effective against many such streptococci, so ineffective in rheumatic fever? To some this forms a strong argument against a direct relationship between rheumatic fever and hæmolytic streptococci.

Treatment.-Unfortunately very little, if any, progress has been made in this direction, and prolonged rest remains almost 
the alpha and omega of therapy. Preliminary studies have indicated that sulphanilamide is of no value; indeed, it seems to be particularly toxic to patients with rheumatic fever." "The toxic action of sulphanilamide in active rheumatic fever so far outweighs the beneficial therapeutic effect that its administration to patients with this disease does not seem justified."79 Tonsillectomy is still practised as a measure of possible value. Vaccines have proved of little worth. Some ${ }^{20}$ expressed the belief that fever therapy is of value. No distinct benefit has been noted from the use of vitamin C. Perhaps too much has been expected of it $;^{78}$ if vitamin $\mathrm{C}$ deficiency prepares the soil for an infection to produce rheumatism, the vitamin deficiency is only contributory and its correction cannot materially affect valvular and other damage.

\section{Sydenham's Chorea}

Chorea has been regarded as (1) a symptom of rheumatic fever; (2) a symptom of several diseases, including rheumatic fever; (3) an independent disease which may accompany rheumatic fever. The first view was supported by three recent reports ${ }^{4}$ which stressed the frequency with which carditis ultimately develops in cases of chorea. The third view was upheld in a report which concerned 137 choreic patients, about half of whom never developed any other signs of rheumatic infection, such as abnormal sedimentation rates or blood counts, carditis or arthritis. ${ }^{80}$ Induced fever continues to be the method of choice in treatment. Several physicians ${ }^{4}$ reported prompt cure of about 80 per cent. or more of patients so treated, marked improvement of others. Remissions were rare and complicating carditis seemed to be benefited. However, two choreic children without carditis developed fatal, uncontrollable fever, induced in one case by injection of typhoid vaccine, in another case by artificial fever therapy. ${ }^{81,82}$

\section{Rheumatoid (Atrophic) Arthritis}

Clinical Data.-Most American physicians feel unable to make a sharp distinction between rheumatoid arthritis and infectious (infective) arthritis. They regard the latter as synonymous with, or at most a clinical variety of, the former. Criteria for the identification of rheumatoid arthritis were suggested as follows:83 (1) Data considered essential-fusiform fingers and 
polyarticular involvement; (2) helpful data, often but not always present-presence of agglutinins for hæmolytic streptococci and the " characteristic" pathologic reactions in synovial tissue and subcutaneous nodules; (3) non-essential data frequently presentvasomotor disturbances, muscle and skin atrophy, presence of antistreptolysins and precipitins, rapid sedimentation rate, " characteristic" roentgenographic changes.

Further observations on the inactivating effect of spontaneous jaundice on rheumatoid arthritis and on primary fibrositis were reported and attempts were made (so far largely unsuccessful) to reproduce the phenomenon by various means, such as use of bile salts, transfusions of jaundiced blood or artificial hyperbilirubinæmia. ${ }^{84,85}$ The strangely beneficial effect of jaundice may be more basic than simply an antirheumatic phenomenon. When one patient developed cinchophen jaundice a " momentous thing " occurred: the patient was promptly relieved not only of his chronic rheumatic symptoms, for which the cinchophen had been taken, but also of symptoms of severe hay fever. The " anti-allergic" effect apparently continued, so that the next year during hay-fever season the patient was able literally to romp in ragweed. ${ }^{86}$

Laboratory Data.-The relative value of laboratory data in diagnosis and in estimating activity and prognosis was studied. Sedimentation rates were the most useful; Arneth-Schilling counts of filamented and non-filamented leucocytes were valuable; the Vernes resorcinol test on serum was less useful. ${ }^{87}$ Results of glucose tolerance tests may sometimes be abnormal in rheumatoid arthritis and in other chronic diseases because of (1) a disturbance of pancreatic function, (2) circulatory disturbances accompanied by removal of sugar from the blood, (3) hepatic dysfunction, the effect of toxæmia on the liver, not on the pancreas. In one series of cases $^{88}$ hepatic dysfunction, as indicated by excretion of azorubin S, affected 55 per cent. of 100 patients with rheumatoid arthritis.

EтTOLOGY.-No significant progress on the problem of ætiology was reported. In recent studies serum agglutinins to hæmolytic streptococci have been found in a lower percentage (only 24 to 53 per cent.) of cases than previously was noted. The significance of these agglutinins is still debated.4, 87 Antifibrinolysins usually are normal, but may be increased in early and acute cases; perhaps the disease is initiated, but not kept up, by hæmolytic strepto- 
cocci. ${ }^{89}$ From current data one cannot certainly conclude that streptococci cause the disease. No new data of significance were reported in favour of the hypothesis of bacterial allergy, of vitamin deficiency, or of " altered metabolism."

Treatment.-Those American physicians who are optimistic about the results of removing foci of infection are still a shade more numerous, or at least more vocal, than the pessimists. The principle of removal of foci usually is " radicalism within the limits of common sense." Vaccines are definitely waning in favour, but many feel justified in using them as non-specific adjuvants; such therapy is being continued, however, in the face of strong criticism..$^{90}$ The empiric use of chaulmoogra oil, given by intramuscular injection, seemed helpful to one physician:91 focal and general reactions, sometimes sterile abscesses, were noted; perhaps the effect is similar to that from non-specific proteins. The evidence suggesting that a primary vitamin deficiency is present or that an excess intake of vitamins $B, C$, or $\mathrm{D}$ is definitely helpful is not striking. Some are still strongly advocating massive doses of vitamin $\mathrm{D}$, but others are abandoning this therapy as useless and sometimes dangerous, and the Council on Pharmacy and Chemistry of the American Medical Association found no scientific evidence to support the claims made for it.4 Causalin (causyth) likewise has been condemned as "unsafe and dangerous," and claims made for "subenon" have been called "ridiculously optimistic."4 Several physicians are still reporting good results from injections of colloidal sulphur, but there seem to be few new converts to this form of treatment, and, as far as $I$ know, it is not being used at any of the larger, more established clinics for rheumatic diseases.

Aware of the number and too frequent severity of toxic reactions to gold, American physicians have been hesitant about using it in spite of the growing favour with which it is regarded in England and on the continent of Europe. Now it would appear that the dangers of chrysotherapy have been considerably lessened by rather sharp reductions in the individual and total doses used. Hence, physicians in several American clinics are studying its effects. Preliminary results in the treatment of one series of twenty-two patients were marked improvement of 54 per cent. with notable reductions in sedimentation rates. ${ }^{92}$ There is a tendency in the United States to give equal doses, not higher than 50 or $100 \mathrm{mg}$. of gold, perhaps twice a week. 
Preliminary results with sulphanilamide have been distinctly disappointing and serious toxic reactions occasionally have been noted.4

Although there are more than 8,000 mineral springs in the United States, there are only twenty or thirty American spas and only four or five of them are really well known. Although almost every community has the services of ill-trained manipulators and adjusters, the supply of medically trained physical therapists is entirely inadequate. Therefore, physicians and physical therapists are waging a quiet campaign to educate intelligent rheumatic patients in those simple and harmless methods of home physical therapy which are so useful and necessary as an adjunct to formal physical therapy. Short-wave therapy has its advocates, but most workers deny that it has a specific or superior mode of action. Results of fever therapy are still not impressive, although they were better in the acute and subacute cases than in chronic rheumatoid arthritis. ${ }^{93}$

\section{OSTEO-ARTHRITIS}

In spite of the great frequency of its occurrence, this disease is a much neglected member of the rheumatism family; few indeed are the publications which have this disease as their sole or chief concern. Surely a disease so prevalent and distressing, even though it is not as serious as rheumatoid arthritis, deserves more serious consideration than to be used almost solely as control material for studies on rheumatoid arthritis. Not a single new clinical report on it appeared in the United States during the period under review. The current writings of our English colleagues have not only been meagre, but have shown little unanimity of opinion even as to the clinical and roentgenographic features of the disease. 4 Two reports ${ }^{94,95}$ described improved methods for making roentgenograms of knees; those made with knees in flexion give better views of intercondyloid fossæ and demonstrate early osteo-arthritic changes not visible in ordinary roentgenograms.

AETroLogy.-The rôle of chronic trauma as a cause of certain types of osteo-arthritis was emphasised in one report; 96 the experimental production of patellar displacement in rabbits caused the development of osteo-arthritic changes similar to those seen in patients with patellar dislocation. According to another 
report ${ }^{97}$ interference with articular blood supply by reason of juxta-articular adiposis dolorosa may be one of the causes of osteo-arthritis of man.

Treatment.-Those who have so enthusiastically advocated sulphur or concentrated vitamin D generally have failed to make any distinction between rheumatoid arthritis and osteo-arthritis, and have claimed good results indiscriminately in both types. Because of this, and because many others have failed to confirm their value, these remedies are in little repute. Fever therapy has been of little value. Some still favour iontophoresis with mecholyl ${ }^{98}$ or with histamine. ${ }^{99}$ A "new" procedure, bone puncture or forage, used as early as 1890 by Nobel Smith, but recently revived, seemed to provide some relief in several cases of osteo-arthritis of hips. ${ }^{100}$

\section{Backache and Sciatica}

Because of recent advances in knowledge of the pathologic physiology of the spinal column, the interest of physicians in cases of backache and sciatica has greatly increased. The idea that certain cases of backache and sciatica are caused by tight fascia lata and ilio-tibial bands, and that complete relief can be obtained by fasciotomy in about 75 per cent. of cases, was again expounded. ${ }^{101,102}$ One surgeon ${ }^{102 a}$ expressed the belief that fasciotomy is of value only as it releases pressure on the pyriformis muscle and sciatic nerve, which pressure he conceives to be the frequent cause of sacro-iliac backache and sciatica. Numerous writers expressed the opinion that in most cases pain in the neck or low in the back, or sciatica, is not due to primary arthritis of the spinal column, but is secondary to, and is rather a late manifestation of, alterations in intervertebral disks- " discogenetic disease." In some instances primary thinning of disks (not due to nuclear prolapse, but possibly the result of chronic trauma) produced narrowed intervertebral spaces and subluxation of articular facets, with resultant segmental neuritis. ${ }^{103.104}$ By proper technique, narrowing of the foramina can be demonstrated roentgenographically. The following were recommended: head traction and neck stretching (Hanflig method, 1936) for cervical lesions, reduction of lumbo-sacral lordosis by plaster jackets, postural exercises, braces or lumbo-sacral fusion for lesions low in the back. 
From two clinics in particular came a series of papers on the syndromes produced by posterior prolapse of intervertebral disks and of nuclei pulposi, ${ }^{105.110}$ the roentgenographic demonstration of filling defects at the site of ruptured disks, and the surgical correction of the lesions. Space does not permit a review of the details of these reports; they were summarised in the Fifth Rheumatism Review. 4 Criteria for a diagnosis of ruptured disks have been established with considerable accuracy and laminectomy should not be performed unless most of the requirements have been met. Prompt and complete relief resulted from laminectomy and removal of protruded disk material in thirty-three of fifty cases $^{109}$ and in thirty-two of fifty-eight cases; ${ }^{106}$ one post-operative death occurred among these 108 patients.

Symptoms similar to those from protruded disks (chronic low back pain generally with sciatica, sometimes numbness of leg or buttock, muscle atrophy or weakness, altered Achilles reflexes) and filling defects in roentgenograms made after injections of lipiodol similar to the defects seen in association with protruded disks also can be produced by hypertrophy of ligamenta flava, according to some.111 Relief was obtained by removing involved laminæ and ligaments.

\section{SPONDYLITIS}

ANKYlOSING SpondyLITIS.-Newer roentgenologic methods were described ${ }^{112}$ for visualising facets and foramina, and it was stated that thereby involvement of lower thoracic apophyseal and costo-transversal joints sometimes can be demonstrated in spondylitis ankylopoietica several years before sacro-iliac involvement.

SPONDYLITIS Osteo-ARTHRITICA.-The present view is that this is not a true form of arthritis, but a form of spondylosis, an exostotic reaction to mechanical irritation arising as a result of degenerative changes in intervertebral disks and vertebral bodies. Contrary to the opinion of many, some now ${ }^{113}$ believe it is not a common cause of low back pain with sciatica. The clinical features in 294 cases of " hypertrophic spondylitis" were reviewed: symptoms affected 99 males and 195 females. ${ }^{114}$ In addition to the usual methods of treatment, gentle traction was advised. ${ }^{112,114}$ 


\section{Godt and Godty Arthritis}

Clinical Data.-Efforts to familiarise physicians with the clinical characteristics of American gout are being successfully carried out and recognition of gout is becoming distinctly more frequent in the United States. However, many cases are still misdiagnosed because of the mistaken notion that the disease is almost non-existent, or at least rare. The classical pattern of gouty arthritis is generally accepted as being one of recurrent attacks with complete symptomatic remissions; later, in some cases chronic gouty arthritis develops. ${ }^{115.117}$ American students of the disease cannot agree with the view expressed by many of their English colleagues that gouty arthritis, especially among women, may appear insidiously, progress slowly without complete remissions, and be chronic from its inception. The tendency for acute attacks to be seasonal in appearance, and often consistently related to certain provocations, was well illustrated in one current series of cases. ${ }^{116}$ The criteria which I use in making the diagnosis of gout and gouty arthritis were restated by my colleagues. ${ }^{116}$ Recently I visited various American physicians interested in gout and summarised their views on the diagnosis and management of the disease. ${ }^{115}$

Aтiology.-Some cannot regard gout as truly a disturbance of purine metabolism, since in gout there is no abnormality of intermediary purine metabolism, although there is an obvious disturbance in the disposition of uric acid. Some consider gout due to a peculiar selective renal insufficiency; others consider it due, not to a primary renal disturbance, but to a functional disturbance of the vegetative nervous system, involving renal innervation. ${ }^{118}$ Among the clinical phenomena correlated with this latter hypothesis were the beneficial effects of cinchophen and the sometimes malevolent effects of ergotamine tartrate (gynergen) on patients with gout.

Treatment.-Too often patients are treated for their gout only during an acute attack; the importance of interval treatment as a prophylactic against chronic gouty arthritis and against the possibly fatal late lesions of gout in kidneys and bloodvessels should be more widely appreciated. In spite of its occasional toxicity, cinchophen is still being used by many physicians of wide experience with gout, not only during attacks, but also intermittently between attacks for long periods. ${ }^{4}$ Others con- 
demn the use of cinchophen under any circumstances, and believe that there is no "safe method" of giving it even if "given cautiously under observation."119 It should be noted, however, that no case of gout has been listed among the few cases of cinchophen toxicity reported in recent years. For those patients who fear, or do not well tolerate, cinchophen the combination of sodium salicylate (60 grains) with amino-acetic acid (glycine) (150 grains) daily during attacks and intermittently thereafter has been used with apparently some success as a substitute for cinchophen. ${ }^{115}$, 116 (In the Fourth Report of this series note was made that Jennings had revived interest in the use of salicylates alone as a substitute for cinchophen.) If it can be shown that salicylates, with or without amino-acetic acid, and with proper dietary control, will effectively control gout, it would be senseless to support the cause of cinchophen longer. Some of us believe that many patients cannot control their gout by diet alone; that many patients can tolerate cinchophen intermittently more readily than the larger doses of salicylates required; and that, in spite of our inadequate knowledge of gout, an attempt to control the hyperuricæmia of gout is sound therapy even though hyperuricæmia may be a secondary, not a primary factor in the disease.

\section{Psoriatic Arthritis}

Cases of psoriatic arthritis are too infrequently recognised; dermatologists tend to ignore the joints; internists ignore the skin; consequently, the possible relationships between the two are not disclosed. Those who accept this entity agree that its diagnosis depends mainly on the close relationship which exacerbations and remissions in skin may bear to those in joints, and on noting the beneficial effects on the joints which not infrequently occur when skin lesions are treated vigorously. Aside from these and a few other rather distinctive features (frequent involvement of terminal phalangeal joints of fingers and toes with associated psoriasis of contiguous nails; sometimes unusual roentgenographic changes in late psoriatic arthritis), this form of arthritis resembles rheumatoid arthritis in many respects. New cases of true psoriatic arthritis (not merely cases of psoriasis incidentally associated with any rheumatism) were described; the application of Goeckerman's (1931) regimen (ultra-violet irradiation and coal- 
tar ointment) resulted in distinct benefit for skin and joints. ${ }^{120} .121$ Of fifteen patients with psoriasis (joints not mentioned) given 300,000 to 400,000 units of concentrated vitamin $D$ for several weeks, the skin of eleven cleared completely..$^{122}$

\section{Allergic, Metabouid and Endocrine Arthritis}

Little appeared to clarify these terms. A number of writers manifested their receptivity to the idea that offending food or bacterial antigens can produce allergic arthritis in susceptible persons. They may be right, but the data given with their reports of cases of the supposed conditions are meagre, incomplete and not convincing. Incapable of accurate definition, the term " metabolic arthritis" is disappearing from American literature; it should not be revived until new discoveries have been made by which the term can be better defined. The terms "endocrine, climacteric and menopause arthritis " also seriously need examination and overhauling, or else they, too, should be discarded. Among the proponents of the entity last mentioned, there is no unanimity of opinion as to whether it is synonymous with osteo-arthritis, whether it is rheumatoid arthritis occurring at the menopause, or whether it is a separate disease. Although writers speak rather glibly of its supposed pathologic characteristics (villous synovitis with degenerative arthritis), no one in recent years, or ever perhaps, has presented any photomicrographic evidence of its supposed characteristic pathologic changes.

\section{INTERMITTENT HYDRARTHROSIS}

In 1929 Weisman-Netter proposed the use of ergotamine tartrate (gynergen) for intermittent hydrarthrosis; by this method the disease apparently was stopped in one recent case. ${ }^{123}$

\section{Fibrositis}

This term is still on probation in the United States. Diagnoses of fibrositis are made and defended by only a few American physicians. One physician noted 262 cases of fibrositis among 900 patients referred to an arthritis clinic. ${ }^{124}$ Still disturbing to American physicians is the almost complete lack of accurate knowledge of the supposed pathologic changes in the disease and the tendency for numerous physicians who write familiarly 
of it to copy rather than to defend and, more important, to extend vigorously Stockman's pioneer work on the pathology of fibrositis. Some of the leading American rheumatologists doubt the existence of the so-called fibrous nodules and, believing that the term "fibrositis" is too often used as a catch-all, refuse to accept the entity. In part one cannot blame them, because certain physicians are likely to perpetuate confuision by adulterating the syndrome of fibrositis with an array of " algias."

The usual methods of treatment are being tried. Apparently unable to improve them, American physicians are still following the precepts of their English colleagues, and, among other things, some of us are, with more hope than faith, still trying to " rub the nodules away." Admitting that he was able to relieve some patients by physical methods and bymassage of nodules, one physician commented: "One is still led to wonder whether these nodules are as important as many writers believe and whether they can be rubbed away as consistently as some state."'125

\section{Campaign against Rheumatism}

To be fully successful a campaign against rheumatism needs occasional dramatisation, special occasions when both the medical profession and the public are informed as to the seriousness of the problem and the amount of physical suffering and economic waste it engenders. But for the ultimate success of such a campaign a sustained, undramatic, slowly progressing growth of interest in the rheumatic diseases among physicians and laymen is much more important than isolated, sporadic days of high resolve. It is along these latter lines that the campaign is being waged in the United States. The American Rheumatism Association now has about 250 members. This association and its parent body, the American Committee for the Control of Rheumatism, have the important and cordial support of the American Medical Association, which has opened its programmes to an increasing number of reports on the problem of rheumatism. The American Rheumatism Association has created associate memberships for interested laymen, social workers, insurance executives and members of professions allied to medicine; to them are sent bulletins summarising information of current interest. The association's conferences on rheumatic diseases, held annually at the time of the meetings of the American Medical Association, 
are increasingly well attended.* New clinical clubs and small groups of physicians are meeting in many of the larger cities for the purpose of special group study of these diseases. New research grants have been made for the establishment of "arthritis units" in several university and city hospitals-for example, at Harvard University, at the University of Michigan and at Welfare Island, New York City. One new large philanthropic foundation is giving a proportion of its funds to individual clinical investigators to aid them in their researches on various phases of the rheumatism problem. In the Commonwealth of Massachusetts, which is perhaps the most progressive in the matter of social legislation as far as the problem of rheumatism is concerned, an Act recently was passed providing for the hospitalisation of a certain number of patients and their treatment for periods as long as six months.

Throughout the world medical science has notably increased the span of man's life, but there is danger that too great a fraction of that lengthened span may be made miserable by the painful symptoms of degenerative arthritis, if not by some more serious articular disability. It is now truly medicine's duty, having added to the quantity of human life, to add also to its quality. Whatever successes are gained by such campaigns against rheumatism will go a long way toward fulfilling that obligation.

\section{REFERENCES}

1. United States Public Health Service (1935-36): "The Magnitude of the Chronic Disease Problem in the United States." National Health Survey, No. 6, $19 \mathrm{pp}$.

2. Roche, Josephine (1938): Journ. Amer. Med. Assoc., 110, 656-665.

* In the spring of 1940 , just prior to the annual meeting of the American Medical Association (to be held in New York City), the American Rheumatism Association will hold its annual conference on rheumatic diseases in connection with the bi-annual meeting of the Ligue Internationale contre le Rhumatisme. Plans are already under way to provide suitable settings for these meetings, and we are looking forward with great pleasure to the opportunity of playing host to our distinguished colleagues from overseas. Tentative plans call for one week of medical and social assemblies in New York City, Philadelphia and Boston. It is to be hoped that the opportunity to attend the sessions of the Ligue, the American Rheumatism Association's conference and the scientific sessions and exhibits of the American Medical Association, as well as to sample the diversions of these American cities, made the more unusual by the presence of the 1940 New York Fair, will appeal to a large number of our colleagues from abroad. 
3. Vonderlehr, R. A., and Usitton, Lida J. (1937): Journ. Amer. Med. Assoc., 109, 1425-1427.

4. Hench, P. S., Bauer, Walter, Dawson, M. H., Hall, Francis, Holbrook, W. P., AND Key, J. A. (1939): Ann. Int. Med., 12, 1005-1104.

5. Keefer, C. S., And Spink, W. W. (1937): Journ. Amer. Med. Assoc., 109, 1448-1453.

6. Warren, C. F., Hinton, W. A., ANd Bauer, Walter (1937): Journ. Amer. Med. Assoc., 108, 1241-1247.

7. Spink, W. W., and Keefer, C. S. (1937): Journ. Amer. Med. Assoc., $109,325-328$.

8. Cromer, J. K. (1937): Med. Ann. District of Columbia, 6, 15-17.

9. Williams, R. H. (1937): Ann. Int. Med., 10, 1766-1774.

10. Hazel, O. G., And Snow, W. B. (1937): Journ. Amer. Med. Assoc. $109,1275-1276$.

11. Gillespie, J. O., ANd Thompson, R. M. (1937): Mil. Surgeon, 80, 418-429.

12. Cohen, Alfred (1937): Journ. Lab. and Clin. Med., 22, 627-637.

13. Carpenter, C. M. (1937): Journ. Amer. Med. Assoc., 109, 1428-1430.

14. KeEFer, C. S., AND SPINK, W. W. (1937): New England Journ. Med., 216, 454-455; Journ. Clin. Invest., 16, 169-176 and 177-183.

15. Bierman, Winliam, ANd Horowitz, E. A. (1937): Amer. Journ. Obst. and Gynec., 34, 68-75.

16. Bierman, William, and Levenson, C. L. (1937): Med. Clin. North America, 21, 1709-1721.

17. Potter, J. E., Redewill, F. H., ANd Longley, E. G. (1937): Journ. Urol., 37, 214-225.

18. Newman, M. K., ANd Berris, J. M. (1937): Physiotherapy Rev., 17, 139-141.

19. Thомas, W. H. (1937): Pennsylvania Med. Journ., 40, 930-934.

20. Srmmons, E. E. (1937): Amer. Journ. Med. Sc., 194, 170-178.

21. Gwynn, H. B. (1937): Med. Ann. District of Columbia, 6, 288-292.

22. Simpson, W. M., ANd Kendell, H. W. (1937): Colorado Med., 34, 782-795.

23. Warren, S. L., Scott, W. W., And Carpenter, C. M. (1937): Journ. Amer. Med. Assoc., 109, 1430-1434.

24. Schnabel, T. G., and Fetter, Ferdinand (1937): Trans. Amer. Climat. and Clin. Assoc.

25. Parsons, E. H., Bowman, P. N., And Plummer, D. E. (1937): Journ. Amer. Med. Assoc., 109, 18-20.

26. Stecher, R. N., ANd Solomon, W. M. (1937): Ann. Int. Med., 10, 1014-1020.

27. Kopp, I., ANd Solomon, H. C. (1937): Arch. Int. Med., 60, 597-622.

28. Hartman, F. W. (1937): Journ. Amer. Med. Assoc., 109, 2116-2120.

29. Long, P. H. (1937): Internat. Surg., 23, 259-265; Amer. Journ. Nursing, 37, 945-950.

30. Long, P. H., and Bliss, Eleanor A. (1937): Journ. Amer. Med. Assoc., 108, 32-37; Arch. Surg., 34, 351-359; South. Med. Journ., 30, 479-487; Ann. Int. Med., 11, 575-592; Canad. Med. Assoc. Journ., 37, 457-465. 
31. Bliss, Eleanor A., and Long, P. H. (1937): Journ. Amer. Med. Assoc., 109, 1524-1528; Bull. Johns Hopkins Hosp., 60, 149-153.

32. Dees, J. E., And Colston, J. A. C. (1937): Journ. Amer. Med. Assoc., 108, 1855 -1858.

33. Reuter, F. A. (1937): Med. Ann. District of Columbia, 6, 117-120; Virginia Med. Monthly, 64, 433-436.

34. Marshall, E. K., Jr., Emerson, Kendall, Jr., and Cutting, W. C. (1937): Journ. Amer. Med. Assoc., 108, 953-957; Journ. Pharmacol. and Exper. Therap., 61, 191-195 and 196-204; Trans. Assoc. Amer. Physicians, 52, 222-223.

35. Brown, A. E., Bannick, E. G., ANd Habein, H. C. (1937): Minnesota Med., 20, 691-697.

36. Mellon, R. R., Gross, Paul, and Cooper, F. B. (1938): "Sulphanilamide Therapy of Bacterial Infections." Springfield: C. C. Thomas, $398 \mathrm{pp}$.

37. Colston, J. A. C., Dees, J. E., ANd HarriLl, H. C.: (1937): South. Med. Journ., 30, 1165-1170.

38. Buchter, H. A., ANd Cook, E. N. (1937): Proc. Staff. Meet., Mayo Clin., 12, 381-383 and 444-447.

39. Ballenger, E. G., Elder, O. F., and McDonald, H. P. (1937): Journ. Amer. Med. Assoc., 109, $1037-1038$; Bull. Crawford W. Long Memorial Hosp., 27 pp.

40. Cheetham, J. G., and Roemer, T. J. (1937) : Northwest Med., 36, 371-376.

41. Drummond, A. C. (1937): Amer. Journ. Surg., 36, 180-188.

42. Goldey, Abert (1937): Urol. and Cutan. Rev., 41, 556-558.

43. Keefer, C. S., AND SPINk, W. W. (1937): Amer. Journ. Syph., Gonor. and Ven. Dis., 21, 241-254.

44. Whitehouse, A. J. (1937): Amer. Journ. Obst. and Gynec., 33, 523-524.

45. Wishengrad, Michaec (1937): Urol. and Cutan. Rev., 41, 578-581.

46. CAVE, E. F. (1937): New England Journ. Med., 217, 853-858.

47. Klennberg, Samuel (1937): Med. Clin. North America, 21, 1723-1737.

48. Chickering, H. T. (1937): Med. Clin North America, 21, 1739-1740.

49. Soule, A. B., JR. (1936): Amer. Journ. Roentgenol., 36, 804-808.

50. HARDy, A. V. (1937): Med. Clin. North America, 21, 1747-1749.

51. Swartout, H. O. (1937): Med. Rec., 145, 319-321.

52. WOODWARD, L. R. (1937): Journ. Iowa Med. Soc., 27, 609-614.

53. Dustin, C. C. (1937): Rhode Island Med. Journ., 20, 73-76.

54. Trueman, K. R., and Allen, E. V. (1937): Proc. Staff. Meet., Mayo Clin., 12, 283-287.

55. Gerschenfeld, Louts, and Butts, D. C. A. (1937): Amer. Journ. Med. Sc., 194, 678-684.

56. HARRIS, H. J. (1937): New York State Journ. Med., 37, 1295-1301.

57. Rosenthal, S. M., Bader, Hugo, and Branham, Sara E. (1937): U.S. Pub. Health Rep., 52, 662-671.

58. Schwentker, F. F., Gelman, Sidney, and Long, P. H. (1937): Journ. Amer. Med. Assoc., 108, 1407-1408.

59. Branham, Sara E., and Rosenthat, S. M. (1937): U.S. Pub. Health Rep., 52, 685-722.

60. Foulis, M. A., AND BARR, J. B. (1937): Brit. Med. Journ., 1, 445-446.

61. ScAL, J. C. (1937): New York State Journ. Med., 37, 1147-1150. 
62. Basman, Jack, And Perley, Anne M. (1937): Journ. Pediat., 11, 212-237.

63. Boyd, C. S. (1937): Med. Clin. North America, 21, 1741-1746.

64. Paul, J. R., and Dixon, G. L. (1937): Journ. Amer. Med. Assoc., 108, 2096-2100.

65. Sharp, W. B., ANd John, Mildred B. (1937): Journ. Infect. Dis., $60,15-24$.

66. Wilson, May G., and Schweitzer, M. D. (1937): Journ. Clin. Invest., 16, 555-570.

67. Hedley, O. F. (1937): U.S. Pub. Health Rep., 52, 164-171; Amer. Heart Assoc., No. 8, 6.

68. Gross, LouIs (1937): Amer. Heart Journ., 13, 275-296.

69. Wearn, T. J., ANd Moritz, A. R. (1937): Amer. Heart Journ., 13, 7-16.

70. Massell, B. F., Mote, J. R., and Jones, T. D. (1937): J. Clin. Invest., 16, 125-128.

71. KeIn, Harry (1937): Ann. Int. Med., 10, 1686-1707.

72. SpInK, W. W. (1937): Arch. Int. Med., 59, 65-81.

73. Messeloff, C. R., and Pomerantz, Anne (1937): Amer. Journ. Dis. Child., 53, 1485-1489.

74. Dwan, P. F., ANd Shapiro, M. J. (1937): Amer. Journ. Dis. Child., 54, 265-276.

75. Bradley, W. H. (1937): Guy's Hosp. Rep., 87, 372-390.

76. Traut, E. F. (1937): Journ. Allergy, 8, 501-505.

77. Chasis, Herbert, and McEwen, Currier (1936): Journ. Immunol., 31, 439-454.

78. RINEHART, J. F. (1937): Internat. Clin., 2, 23-36.

79. Swift, H. F., Moen, J. K., ANd HIRst, G. K. (1938): Journ. Amer. Med. Assoc., 110, 426-434.

80. Coburn, A. F., and Moore, Lucine V. (1937): Amer. Journ. Med. Sc., $193,1-4$.

81. Schnabel, T. G., and Fetter, Ferdinand (1936): Trans. Amer. Therap. Soc., 35, 120-123.

82. Parrish, P. L., Taran, L. M., and Starr, Saul (1937): Journ. Pediat., 11, 617-625.

83. CeCIL, R. L. (1937): Ann. Int. Med., 11, 637-642.

84. Hench, P. S. (1937): Journ. Amer. Med. Assoc., 109, 1481-1484; (1938) Brit. Med. Journ., 2, 394-398; Proc. Internat. Congress Rheumatism and Hydrology and Bath Bi-Centenary Congress on Chronic Rheumatism, 315-331; Arch. Int. Med., 61, 451-480, 495-500.

85. Thompson, H. E., and Wyatr; B. L. (1937): Journ. Amer. Med. Assoc., 109, 1481-1484; (1938) Arch. Int. Med., 61, 481-500.

86. Boros, Edwin (1937): Journ. Amer. Med. Assoc., 109, 113-115.

87. Short, C. L., Dienes, Louis, and Bauer, Walter (1937): Journ. Amer. Med. Assoc., 108, 2087-2091.

88. Rawls, W. B., Weiss, Samuel, and Collins, Vera L. (1937): Ann. Int. Med., 10, 1021-1027.

89. Dawson, M. H. (1937): Med. Clin. North America, 21, 1663-1670.

90. Jordan, E. P. (1937): Journ. Amer. Med. Assoc., 109, 1444-1445.

91. Robinson, A. H. (1937): Tri-State Med. Journ., 9, 1838-1841. 
92. SAShin, D., ANd Spanbock, J. (1937): Med. Rec., 145, 429-432.

93. Stecher, R. M., ANd Solomon, W. M. (1937): Amer. Journ. Med. Sc., 194, 485-492.

94. Holmblad, E. C. (1937): Journ. Amer. Med. Assoc., 109, 1196-1197.

95. Jordan, H. (1937): Arch. Phys. Therapy, 18, 348-357.

96. BennetT, G. A., AND BAUER, WAlter (1937): Journ. Bone and Joint Surg., 19, 667-682.

97. KLING, D. H. (1937): Arch. Surg., 34, 599-630.

98. Martin, Lay, and Eaton, G. O. (1937): Arch. Phys. Therapy, 18, 226-232, 237.

99. KlIng, D. H., AND SAShIn, D. (1937): Arch. Phys. Therapy, 18, 333-338.

100. Henderson, M. S. (1937): Proc. Staff Meet., Mayo Clin., 12, 579-581.

101. Ober, F. R. (1937): Journ. Amer. Med. Assoc., 109, 554-556.

102. Sмгтн, A. D. (1937): Journ. Bone and Joint Surg., 19, 765-769.

102a. Freiberg, A. H. (1937): Arch. Surg., 34, 337-350.

103. Oppenhermer, Albert, ANd TURner, E. L. (1937): Amer. Journ. Roentgenol., 37, 484-493.

104. Wrlliams, P. C. (1937): Journ. Bone and Joint Surg., 19, 343-363.

105. BARR, J. S. (1937); Journ. Bone and Joint Surg., 19, 333-342.

106. Bark, J. S., Hampton, A. O., AND Mixter, W. J. (1937): Journ. Amer. Med. Assoc., 109, 1265-1270.

107. Mixter, W. J. (1937): Ann. Surg., 106, 777-787.

108. Hampton, A. O., and Robinson, J. M. (1936): Amer. Journ. Roentgenol., 36, 782-803.

109. Love, J. G., AND CAMP, J. D. (1937): Journ. Bone and Joint Surg., 19, 776-804.

110. CAMP, J. D. (1937): Proc. Staff Meet., Mayo Clin., 12, 373-377.

111. Spurling, R. G., MAYField, F. H., AND Rogers, J. B. (1937): Journ. Amer. Med. Assoc., 109, 928-932.

112. OpPENHEIMER, Albert (1937): Radiology, 28, 582-592; Ann. Surg., 106, 428-440.

113. Hodges, F. J., ANd Peck, W. S. (1937): Amer. Journ. Roentgenol., $37,461-466$.

114. KuHNS, J. G. (1937): New England Journ. Med., 217, 317-321.

115. Hench, P. S. (1937): Proc. Staff Meet., Mayo Clin., 12, 262-269.

116. Rutledge, D. I., ANd Bedard, R. E. (1937): Proc. Staff Meet., Mayo Clin., 12, 149-156.

117. Volini, I. F. (1937): Med. Clin. North America, 21, 3-9.

118. GrabField, G. P. (1937): Ann. Int. Med., 11, 651-656.

119. Palmer, W. L., Woodall, P. S., ANd WaNG, K. C. (1936): Trans. Assoc. Amer. Physicians, 51, 381-393.

120. Jeghers, Harold, And Robinson, L. J. (1937): Journ. Amer. Med. Assoc., 108, 949-952.

121. Lane, C. G., ANd Crawford, G. M. (1937): Arch. Dermat. and Syph., $35,1051-1061$.

122. Ceder, E. T., ANd Zon, Leo (1937): U.S. Pub. Health Rep., 52, $1580-1584$.

123. Соок, C. K. (1937): Med. Rec., 145, 300.

124. Traeger, C. H. (1937): Med. Clin. North America, 21, 1797-1806.

125. Krusen, F. H. (1937): Arch. Phys. Therapy, 18, 687-697, 722. 